\title{
The Importance of Archival and Herbarium Materials in Understanding the Role of Oospores in Late Blight Epidemics of the Past
}

\author{
Jean B. Ristaino
}

Department of Plant Pathology, North Carolina State University, Raleigh.

Accepted for publication 28 July 1998.

\begin{abstract}
Ristaino, J. B. 1998. The importance of archival and herbarium materials in understanding the role of oospores in late blight epidemics of the past. Phytopathology 88:1120-1130.

Nineteenth and early twentieth century botanists and mycologists collected healthy and infected plant materials from many regions of the world. Some of these plant collections preserved in herbaria around the world contain samples that are of considerable significance to epidemiologists, population biologists, and botanists. The advent of the polymerase chain reaction (PCR) and the development of molecular marker technology has made DNA amplification from herbarium material a reality. In this mini-

ical role of oospores in the biology of the potato late blight pathogen. DNA was successfully amplified by PCR with the Phytophthora infestansspecific PCR primer, PINF, and the universal primer, ITS 5, from oospores observed in a field sample of potato collected by G. P. Clinton in 1902. This experiment demonstrates the potential to utilize molecular methods to amplify DNA from historical samples of the late blight pathogen and represents the earliest definitive record of oospores of the pathogen in field samples in the United States. Studies based upon such materials and techniques, although high risk and laborious, have the potential to open a new window to epidemics of the past.
\end{abstract} review, archival letters and herbarium samples are used to track the histor-
Additional keywords: oomycetes.
The tools of molecular biology coupled with herbarium specimens offer a unique approach to address questions never before possible concerning the nature and source of populations of old epidemics and the migration of plant pathogens worldwide. It is the purpose of this mini-review to use the late blight pathogen Phytophthora infestans (Mont.) de Bary as a model to illustrate how archival letters and herbarium materials can be used to help clarify present day questions about the role of oospores in the biology of this disease.

Late blight of potato caused by the pathogen Phytophthora infestans led to the devastating Irish potato famine. Nineteenth and early twentieth century scientists including M. J. Berkeley, C. Montagne, D. Moore, J. Lindley, A. DeBary, W. G. Smith, A. S. Wilson, W. G. Farlow, G. P. Clinton, L. R. Jones, R. Thaxter, and many others collected and preserved potato and tomato leaves infected with the pathogen (Fig. 1A). These scientists also corresponded and sent late blight samples between Europe and the United States. These intriguing early letters, written by some of the pioneering scientists in our discipline, were often attached to the herbarium samples and revealed their thinking about the role of oospores in the biology of the late blight pathogen. It is clear from evaluating both historical late blight specimens and archival letters that our current views on the role of oospores in the biology of Phytophthora infestans have not completely considered those of early pioneers in the field of plant pathology. Taken together, these letters, drawings, and specimens illustrate misinterpretation in the pathogen's life cycle and can also help us document when oospores of Phytophthora infestans were actually first observed in field samples.

Corresponding author: J. B. Ristaino; E-mail address: Jean_Ristaino@ncsu.edu

*The e-Xtra logo indicates the electronic version of this paper available on APSnet contains enhancements.

Publication no. P-1998-0901-01V

(C) 1998 The American Phytopathological Society

\section{WHY STUDY HERBARIUM MATERIALS?}

Herbaria and museum collections offer a valuable time capsule of genetic information on both extinct and extant species $(43,44)$. Herbarium specimens provide information on the population biology of the past and are useful for studies of changing genetic structure (43). Disputes about taxonomy, nomenclature, phylogenetics, function and evolution of genes, and origins of populations can be addressed using herbarium specimens $(11,79)$. Genomes of pathogens are preserved in herbaria collections, making them a valuable genetic repository that can be used to sample populations when coupled with the use of polymerase chain reaction (PCR) technology (64).

Molecular studies have been conducted using herbarium specimens $(10,30,35)$. Bruns et al. (10) used PCR to amplify DNA from 35 collections of dried fungi obtained from four different herbaria. DNA was extracted and a portion of the mitochondrial, large subunit, ribosomal RNA gene was amplified. DNA sequences from cloned, dried voucher specimens were identical to those from DNA from current cultures, which demonstrates the usefulness of the technique (10). Doyle and Dickson (30) extracted enough highmolecular-weight DNA from 12-year-old dried Solanum leaves to visualize typical restriction fragment patterns by hybridization to cloned ribosomal DNA. Recently, the evolution of tobacco mosaic tobamovirus (TMV) and tobacco mild green mosaic tobamovirus (TMGMV) in Australia was elucidated using herbarium specimens (35). Infectious virions were obtained from herbarium material, and the virus was extracted and sequenced. The data of Fraile et al. (35) demonstrate that TMV populations colonized New South Wales earlier than TMGMV, but TMV populations decreased over time because of Muller's rachet or mutational meltdown of TMV populations.

\section{WHAT QUESTIONS CONCERNING THE BIOLOGY OF THE LATE BLIGHT PATHOGEN CAN BE ADDRESSED WITH HERBARIUM MATERIAL?}

The role of oospores in epidemic ontogeny in the field has been controversial since the pathogen was first described. Phytophthora 
infestans reproduces predominately by asexual means and forms sporangia on infected host tissue that either germinate directly or release zoospores that are responsible for infection (38). The pathogen typically survives from season to season as mycelium in infected potato tubers and debris when the asexual cycle is predominant (83). It is currently believed that, before the 1980 s, the populations of Phytophthora infestans worldwide consisted primarily of only a single mating type (A1) and, therefore, had been limited to asexual reproduction for more than 150 years (37). Oospores were reported in abundance in plant tissue in Mexico, and the discovery of the A1 and A2 mating types occurred there in the 1950s $(39,78)$.

It is generally assumed that, because the A2 mating type was not found in the United States or Europe until the 1980s, pathogen reproduction was strictly asexual $(31,37,55)$. This may not be a valid assumption. In this paper, herbarium specimens will be used to determine whether oospores of Phytophthora infestans occurred in plant material from the field prior to the discovery of the A2 mating type in Europe, Mexico, and the United States (12,24,39, 45,69). Morphological evidence of oospores in herbarium tissue cannot definitively allow distinction between outcrossed (heterothallic hybridization) and selfed (homothallic hybridization) populations of the pathogen; however, the presence of oospores that are identified clearly as Phytophthora infestans would provide strong evidence that the pathogen was not reproducing strictly by asexual means before the 1980s. Recent data indicate that the relative abundance of A1 versus A2 mating types may actually be less important in the life cycle of Phytophthora infestans than the inherent properties of individual isolates of Phytophthora infestans to selfhybridize and form oospores $(50,81)$. Oospores formed as a result of self-hybridization or induction by fungicides are capable of germination and have the potential to serve as an overwintering inoculum source in the field $(68,81)$, and thus, cannot be dismissed as unimportant in the life cycle of the pathogen (41). Use of appropriate molecular markers could be used to distinguish outcrossed from selfed populations and may be useful with herbarium samples $(36,49,51)$.

A second set of questions concerns the center of origin of the late blight pathogen and the source inoculum for the 1840s' epidemics in the United States and Europe. One theory proposes that Mexico represents the center of origin and diversity of the late blight pathogen and provided the source inoculum for the late blight epidemics of the 1840 s $(8,40,55,63)$. These hypotheses are based on a recent analysis of worldwide populations of Phytophthora infestans that were dominated by a single clonal lineage known as the US-1 "old" genotype $(38,40)$. A second theory proposes that Peru represents the center of origin of Phytophthora infestans and that source inoculum for the 19th century epidemics originated there $(1,3,33)$. This theory is based on historical writings that indicate the disease may have been endemic in the Andean region for centuries. A third theory suggests that Mexico represents the center of origin of the late blight pathogen, but that source inoculum for 19th century epidemics in Europe and the United States originated from Peru, where only the US-1 genotype has occurred until relatively recently and where the disease was reported in the 19th century and earlier $(2,8,80)$. Herbarium specimens could be used to track 19th century migration patterns of the pathogen. Epidemics of the disease occurred in both the United States and Europe and may have been caused by different sources of inoculum. Was the same genotype responsible for the U.S. epidemics that began in Philadelphia and for the European epidemics that began in Belgium in the 1840 s?

Migration of new genotypes of Phytophthora infestans have clearly occurred from Mexico in recent times with the movement of potatoes. These migrations have complicated disease management strategies, because these new genotypes are displacing old genotypes, are metalaxyl insensitive, and are more pathogenically aggressive than genotypes reported previously $(37,42,55)$. Actual late blight-infected herbarium specimens from the 19th century have not been used in DNA studies to attempt to support or refute the current origin and migration theories. Research is underway in my laboratory with herbarium specimens to delineate 19th century migration patterns.

\section{WHAT ROLE HAVE OOSPORES PLAYED IN THE HISTORICAL BIOLOGY OF PHYTOPHTHORA INFESTANS?}

Putative oospores of Phytophthora infestans have been repeatedly associated with the late blight disease since its first description in 1846. The Rev. Miles Joseph Berkeley in England published some of the first descriptions and sketches of the late blight pathogen, then called Botrytis infestans Mont., in 1846 (Fig. 2) (3). Berkeley's major contribution to the science of plant pathology was to provide evidence that it was not a change in climate but the pathogen Botrytis infestans that was the cause of late blight of potatoes. Montagne, a retired surgeon from Napoleon's army in Paris, sent Berkeley his sketches of Botrytis infestans, which Berkeley studied and included in his description of the species (Fig. 2) (3). Montagne also communicated information to Berkeley about a fungus observed by Dr. Rayer in Paris that was growing in the intercellular spaces of decaying potato tubers. Montagne named this fungus Artotrogus hydnosporus, and Berkeley published these descriptions (3). Berkeley believed that oospores were associated with the disease and preserved Montagne's specimen for others to examine years later $(29,71,72)$. Montagne's original specimen and drawings of the fungus (Fig. 3A and B) are preserved in the Mycology Herbarium in the Royal Botanic Garden, Kew, England. Montagne's specimen was examined microscopically, and oospores were observed that were brown and reticulate (Fig. 3C). These oospores from Artotrogus hydnosporus clearly were not the sexual stage of Phytophthora infestans, since oospores of Phytophthora infestans are smooth walled and hyaline. Berkeley and Montagne had described another fungus found in association with late blight-infested tissue.

In 1872, significant late blight epidemics again struck in the British Isles (53). The mycologist Anton DeBary of Strasbourg had published papers in 1861 and 1863 in which he delineated the asexual stages in the life cycle, studied the survival, and looked for the overwintering stage of the pathogen $(25,26)$. The Royal Agricultural Society of England commissioned DeBary to continue research on Peronospora infestans (reclassified by Caspary in 1852). He reported to the Royal Agricultural Society in December 1875 that "up to this time the sexual organs have not been observed in Phytophthora, the potato-fungus." DeBary reclassified the pathogen into the genus Phytophthora, studied closely related oomycetes, and made inferences about where the overwintering spores might be found (29).

In a series of publications between 1875 and 1876, Worthington G. Smith, the principal artist on the staff of the Gardener's Chronicle, claimed to have found the true resting spores of Phytophthora infestans (70-77). Smith made his first announcement of the discovery of the oospores of Phytophthora infestans on 10 July 1875 (73) and 2 days later was awarded a gold medal by the Royal Horticultural Society (53). Smith was a scientific illustrator and produced a series of sketches of the resting spores and a watercolor painting of a cross section of a potato showing the sexual and asexual spores of Phytophthora infestans. This watercolor is preserved in the Mycology Herbarium at the Royal Botanic Garden (Fig. 1B) $(73,76)$. Smith claimed that the resting spores he observed were the same as the spores observed by Montagne in 1846 in Artotrogus hydnosporus (Fig. 3C) (75).

DeBary was critical of Smith's publications on the so-called resting spores of Phytophthora infestans in his report to the Royal Horticultural Society in December 1875 (29). Close examination of Smith's drawings (Fig. 1B) indicated several problems with the discovery. First, DeBary claimed that Smith did not "accurately know the co- 
nidiophores of the potato-fungus" and had drawn them incorrectly (29). Secondly, Smith illustrated septate hyphae bearing oogonia and antheridia and showed antheridia that were borne on distinctly separate mycelial threads. Antheridia were paragynous, and hyphal widths differed between oogonial and antheridial mycelium. In addition, the oospores were dark brown and not smooth walled. DeBary claimed that W. G. Smith's so-called resting spores were not associated with Phytophthora infestans at all, but were another fungus. DeBary named the fungus Pythium vexans, since it had been a contaminant in his work with the true late blight pathogen (29).

William G. Farlow, who earned undergraduate and medical degrees from Harvard University, was appointed as an assistant to Asa Gray, professor of natural history at Harvard in 1870 (67). After 2 years in that position, Farlow, at the encouragement of Gray, left for Europe and studied for part of that time under the direction of DeBary in Strasbourg. Upon his return to the United States in 1874, Farlow was appointed assistant professor of botany at Harvard's Bussey Institution (67). Farlow communicated with many European scientists including Berkeley and DeBary about the potato blight fungus, and specimens were sent between these scientists.

The Farlow Herbarium at Harvard contains the world's most extensive collection of intact exsiccatae of fungi, many of which were acquired under the direction of Farlow (59). A note attached to a specimen sent by Berkeley to Farlow stating "see letter of June 26, 1875" is preserved in the Farlow Reference Library Archives. Berkeley wrote to Farlow, "The disease appears to resemble the 'curl' which has been unknown in England for many years. Have you any such disease in America, or has it originated here from change of climate. You will oblige me very much by making a early inquiry about the matter" (4). Apparently, Berkeley was asking
Farlow for advice on the identification of the pathogen in the specimen. The following week, on 10 July 1875 , Berkeley followed up with a second letter to Farlow, "My Dear Sir, I forgot whether when I wrote a few days since I told you that I found in the diseased potato leaves what I considered as a Protomyces. Worthington Smith has since proved that these are the resting spores of the Peronospora, or rather the condition of the male and female organs before impregnation. He has seen the perfect Peronospora with zoospores in the fruit growing from the same mycelium which has the so called Peronospora/Protomyces. Before you get this you will probably have seen the account in the Gardener's Chronicle. Figures will be given next week. Believe me very sincerely yours. M. J. Berkeley. P.S. This is a very rough sketch just to tell you what to look for. Have you not lately written a report on the potato disease? If so I should be glad to have it" (5). Berkeley's drawing included with the letter shows an oogonia and antheridia of what he believed to be the perfect state of Phytophthora infestans (Fig. 4).

Farlow wrote a letter back to Berkeley later that year on 18 November 1875, which was attached to a specimen now in the Mycology Herbarium at the Royal Botanic Gardens (32). "Yesterday, I received a copy of Worthington Smith's account of the potato rot which you were so kind as to send me and for which I am very much obliged. In August, I sent notices to a large number of botanists asking them to send specimens of leaves offended with the rot. Only one person responded who sent some of the enclosed material. I have examined the tissue carefully but find no traces of oospores whatsoever. I have myself examined potato plants growing near Boston for oospores but without success although the disease prevails until the middle of October. I hope next month to send you a few things which I have collected during the summer.
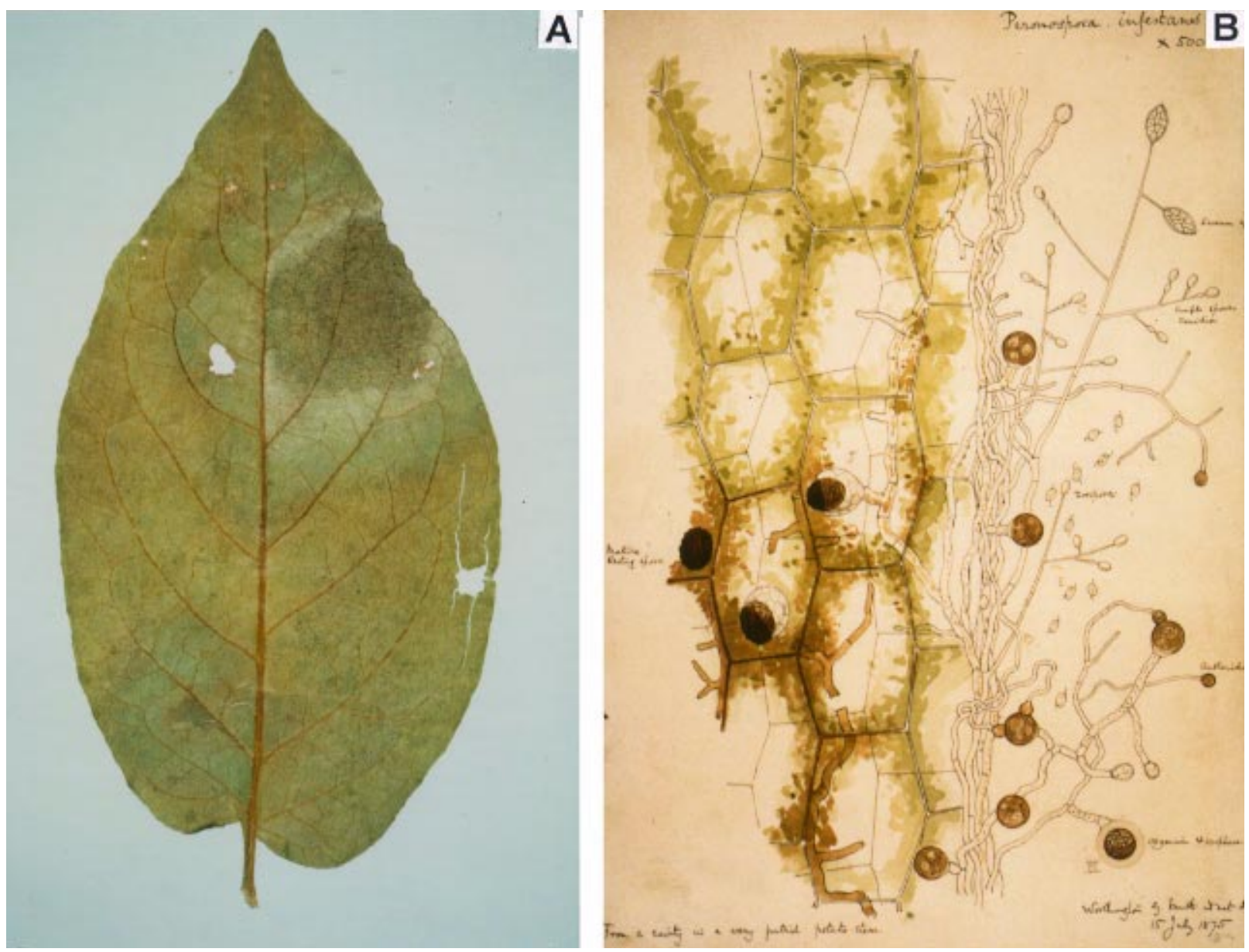

Fig. 1. A, Lesion caused by Phytophthora infestans on potato leaf collected in Germany by K. W. Kreiger in 1888. Specimen from Fungi Saxonici number 398 and deposited in the U.S. National Fungus Collections, USDA, Beltsville, MD. B, Watercolor painting done on 15 July 1875 by Worthington G. Smith of a cross section of a potato stem showing the putative resting spores of Phytophthora infestans. Painting deposited in the Royal Botanic Garden Mycology Herbarium, Kew, England. 
At present I am busy in the next number of the Bussey Bulletin in which I am to have an account of some of our injurious plants. Very respectfully, W. G. Farlow, 6 St James Ave" (32).

DeBary also communicated with his former protégé Farlow on the subject of late blight $(27,28)$. Two letters written in German (translated by H. Meissner, North Carolina State University, Raleigh) from DeBary to Farlow on the subject of oospores are also preserved in the Farlow Reference Library Archive at Harvard University. On 10 December 1874, DeBary wrote to Farlow, “As far as the fungi are concerned which you have recently collected yourself, I would like to see the Peronospora soon. Momentarily, they are for me of interest only in as much as it can be useful for the slowly progressing revision of The Life History of the Potato-Fungus to know and compare American forms" (27). DeBary also went on to tell Farlow, "By the way, I believe I am about to discover the secret of the oospores of Peronospora infestans" (27).

A year later, on 25 December 1875, DeBary wrote to Farlow, "I also want to finish my potato-rot [paper] now. I haven't made much progress with it and have hesitated for a long time to say anything about it, because I wasn't sure about the questionable discovery of Worthington Smith. With much effort I have now seen enough material from England to be sure that the studies as they are right now, are muddled and unreliable. It is possible that they are based on valid facts, but I doubt it very much. In any case this is very unsure and must be started from the beginning. If you look at his [Smith's] publications you will see that immediately. Specimens like the ones he shows in the Gardener's Chronicle are impossible:

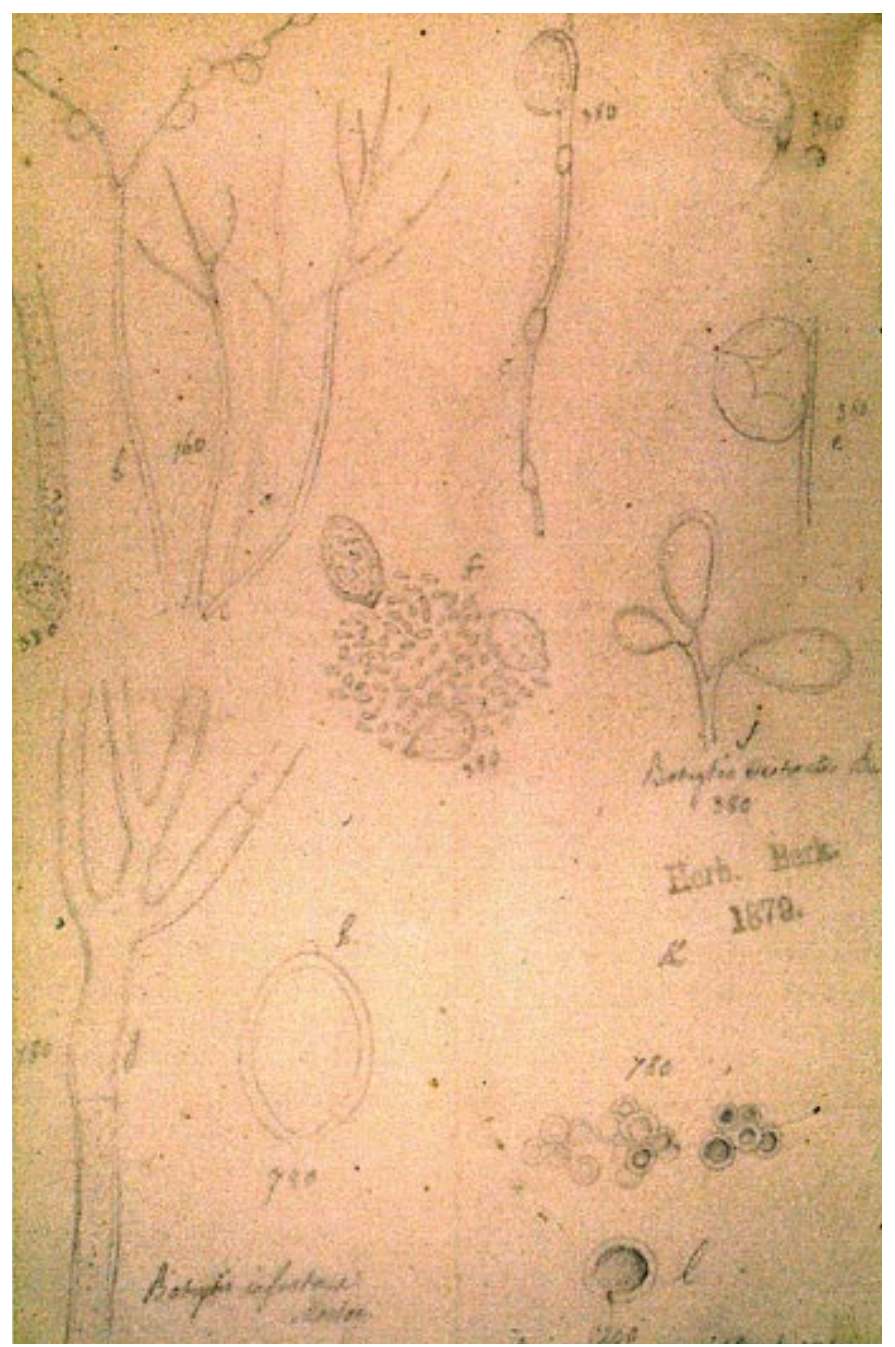

Fig. 2. Hand-drawn sketches of Botrytis infestans drawn by C. Montagne from the original collection of M. J. Berkeley, 1846. Sketches deposited in the Royal Botanic Gardens Mycology Herbarium, Kew, England. the specimen that I have seen from him look very differentmiserable — and could be anything as well as P. infestans." DeBary went on to say, "Note especially that he obtains oospores from material which was [immersed] in water. Last July we had an incredible amount of $P$. infestans here. At that time, Smith's first communication had appeared in Nature and I believed it. We searched piles of material for oospores, but didn't get any further than 15 years ago. Have somebody search in the South and West of America. There you will find the oospores, maybe on some other species of Solanaceae, maybe on Scrophulariaceae" (28).

Farlow published a paper called "The Potato Rot" in 1875 in the Bulletin of the Bussey Institute, in which he supports DeBary's
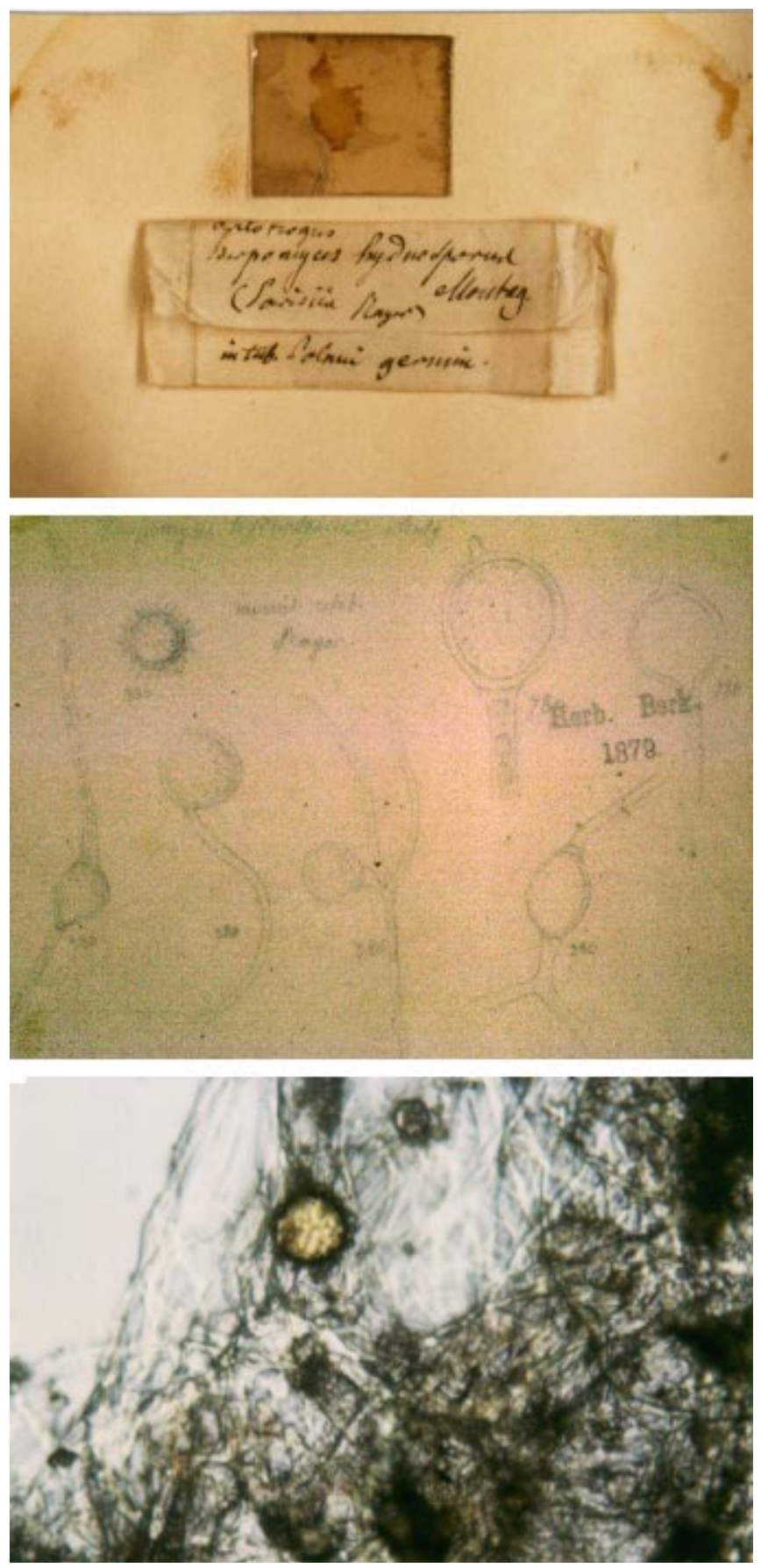

Fig. 3. Herbarium specimen from the collection of M. J. Berkeley. Top, The fungus Artotrogus hydnosporus encased in mica discovered by Rayer and described by C, Montagne, 1845. Middle, Hand-drawn sketch of the life stages of the fungus. Bottom, Recent microscopic view of the warty brown oospores of Artotrogus hydnosporus observed at $\times 40$ magnification. Specimens deposited in the Royal Botanic Gardens Mycology Herbarium, Kew, England. 
ideas on the source of oospores of the pathogen. Farlow stated, "In the case of Peronospora infestans, the oospores have never been discovered, and consequently, the true systematic position of this fungus is uncertain. The more probable supposition would be that the disease, as well as the potato, was imported from Peru, and that, in that country, the Peronospora lives upon different species of Solanum, of which there are a good many that inhabit Peru, and that, although when growing on the potato only asexual spores are produced, yet on other species of Solanum, oospores as well are found. If this last supposed species of Solanum has not yet been introduced into Europe or North America, that is a sufficient reason why we know nothing about the oospores" (33). The following year in 1876 in Farlow's "Synopsis of the Peronosporaceae of the United States," he lists under Peronospora infestans, "Oospores (Artotrogus hydnosporus, Mont. Fide Berkeley) dark brown, coarsely reticulate," as Berkeley had done in $1846(3,34)$.

Smith tried to counter DeBary's claims about the resting spores he had described in a paper published the following year by sending his samples to others for verification (75). Smith sent some of his material to other mycologists including M. J. Berkeley, C. W. Plowright, J. E. Vize, and C. E. Broome, who supported his claims $(61,62,76,77)$. Plowright also collected additional specimens of the late blight pathogen (Fig. 5) and observed oospores in the vascular tissue of potato stems $(61,62)$. Numerous specimen labels from Plowright's collections from 1876 indicate the presence of oogonia and oospores in leaves and tubers (Fig. 5A, D, E, and F). One sample contains potato haulms (Fig. 5B). Sections were made and examined from the 19th century specimen shown in Figure 5B, and oospores that resemble the oospores of Phytophthora infestans were found (Fig. 3C).

In a letter to Joseph Hooker, director of the Royal Botanic Gardens, Berkeley wrote on 25 March 1876, "I have been carefully looking at Smith's mounted specimens and I find almost everything that he figures, and I am the more convinced that DeBary's criticisms are most unjust. I believe that his bodies are truly the rest-

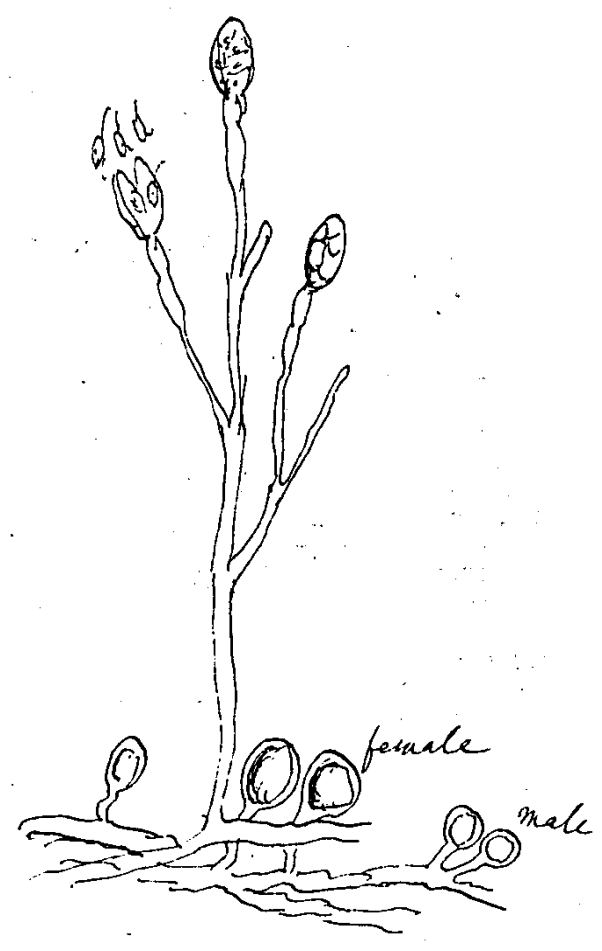

Fig. 4. Hand-drawn sketch by M. J. Berkeley enclosed in a letter to W. G. Farlow at Harvard University on 10 July 1875 showing the sporangiophore, sporangia, zoospores, oogonia (female), and antheridia (male) of Phytophthora infestans. Letters deposited in the Farlow Library Archives, Harvard University. ing spores, though from his want for a complete knowledge of the subject, he may have fallen into some error, at the moment he becomes himself critical" (6). Berkeley also communicated on 8 April 1876, in a letter to a British colleague (probably John Firminger Duthie) that is preserved in the herbarium at the Royal Botanic Garden, "I was very sorry not to see you on April 5 as some very curious observations were brought forward by Smith. I have examined light slides sent me by Smith and have found all the elements of his observation. I am convinced that the Artotrogus is a state of Pythium ornatum. I believe the whole to be connected with Peronospora infestans and that therefore DeBary's genus Phytophthora is a good genus." Berkeley went on to say, "Whatever may be the ultimate judgement reflecting the nature of these bodies, Smith will at least earn the credit of calling attention to them, and DeBary's criticisms are I think most unjust and it is a pity that Carruthers [of the British Museum and consultant for the Royal Society of Agriculture in London] supports him" (7). DeBary wrote in his paper of 1875 , "Even if these warty bodies were the hibernating oospores of the Phytophthora, we should not gain much information bearing upon these questions since their occurrence is, at best, extraordinarily rare" (29). Present day researchers have made similar comments about the role of oospores in late blight epidemics of the past (41).

These series of letters indicate the growing controversy over the existence of oospores in Phytophthora infestans. DeBary and Farlow were of the opinion that the resting spores of the pathogen would eventually be found in South America. On the other hand, Smith, Berkeley, and Plowright believed they had observed the true oospores of Phytophthora infestans in potatoes from European fields.

\section{EVIDENCE OF OOSPORES OF PHYTOPHTHORA INFESTANS IN THE UNITED STATES}

G. P. Clinton, a botanist at the Connecticut Agricultural Experiment Station from 1 July 1902 to 30 June 1937, served as a lecturer in forest pathology at Yale from 1926 to 1929 and was the 12th president of The American Phytopathological Society (54). Clinton is credited with the first reports of true oospores of Phytophthora infestans in pure culture. His interest in late blight was unending throughout his career, and only a few days before his death, he spent an entire day in a potato field looking for late blight (54). Clinton received a Ph.D. in botany under the direction of Farlow at Harvard University in 1901 (54). He obtained the position at the Connecticut Agricultural Experiment Station formerly held by Roland Thaxter after Thaxter moved to Harvard in July 1902. When Clinton arrived at the Experiment Station in 1902, late blight was causing serious problems on the potato crop.

One objective of Clinton's early work was to determine the conditions necessary for oospore production of Phytophthora phaseoli in artificial culture $(17,18)$. Clinton wrote to Farlow in a letter on 25 November 1905, "I have discovered the oospores of Phytophthora phaseoli and have succeeded in raising them in artificial cultures of cornmeal. This I believe is the first time the oospores of any of the Peronosporaceae have been grown artificially" (13). Clinton wrote to Thaxter on 13 November 1908, "I have had some fine cultures of $P$. phaseoli this fall producing oospores. I thought I was going to prove the strain theory as the antheridia seem to be on different threads from the oogonia but so far I have been unable to grow cultures in which oospores are not produced and now my cultures seem to be going back on me just as they did before in my first work a few years ago. The cultures were so much better this time that I thought they would keep going" (16). Clinton did not realize that Phytophthora phaseoli was a homothallic Phytophthora species. Clinton wrote in a paper in 1909 when comparing Phytophthora infestans with Phytophthora thalictri and Phytophthora phaseoli, "To account for their [oospores] absence in the potato mildew, especially in artificial cultures, the writer suggested that these fungi may have distinct sexual mycelia" (18). 
Clinton had a keen interest in the occurrence of oospores of the late blight pathogen in nature and looked for oospores in tissue for many years. On 10 April 1906, Clinton wrote to Farlow, "Dear Professor Farlow, In his book on plant diseases, Worthington Smith makes the statement that the Rev. Vize had specimens of the oospores of Phytophthora infestans for sale. If you have a set of Vize's exsiccati are there any of these oospores? Are either Smith or Vize now alive and if so can you give me their addresses? Clinton" (14). On 15 December 1906, Clinton wrote to Thaxter at Harvard, "Have not gotten any further with my studies of potato blight, as it was very inconspicuous this year, but have set my heart on the discovery of the oospores and the reason they have not been before found" (15). Clinton was successful in his contact with Smith. Smith wrote to Clinton in 1908, "No doubt you know that the oospores became a kind of political subject-oospores of $P$. infestans or no oospores of $P$. infestans?-and I had no wish to go on. Botanists and popular writers followed what they took to be the safer authority, just as Saccardo has done; this is right enough in a way" (22). Clinton examined Smith's drawings and concluded "the writer is led to the conclusion that he [W. G. Smith] did not find the oospores of $P$. infestans" (22).

Clinton succeeded in culturing Phytophthora infestans and producing oospores on artificial media. On 4 February 1910, Clinton wrote to Farlow at Harvard, "I have been getting some bodies almost like oospores in some of my potato blight cultures but as yet can not increase them in amount or further in activity" (21). In 1911, he published "Oospores of Potato Blight" in Science (22). He clearly demonstrated the cultural characteristics necessary for the production of oospores of the pathogen and tested various media (19). Clinton stated that "one of the best tubes produced about 100 oospores, in different stages of development, on a single slide from it" (19). In addition, he tested his mycelial strain theory by crossing the fungus with other isolates of Phytophthora infestans, Phytophthora cactorum, and Phytophthora phaseoli (22). The isolates of Phytophthora infestans Clinton used in his crosses were from Connecticut, Maine, New York, Vermont, and Holland (19). Appar-
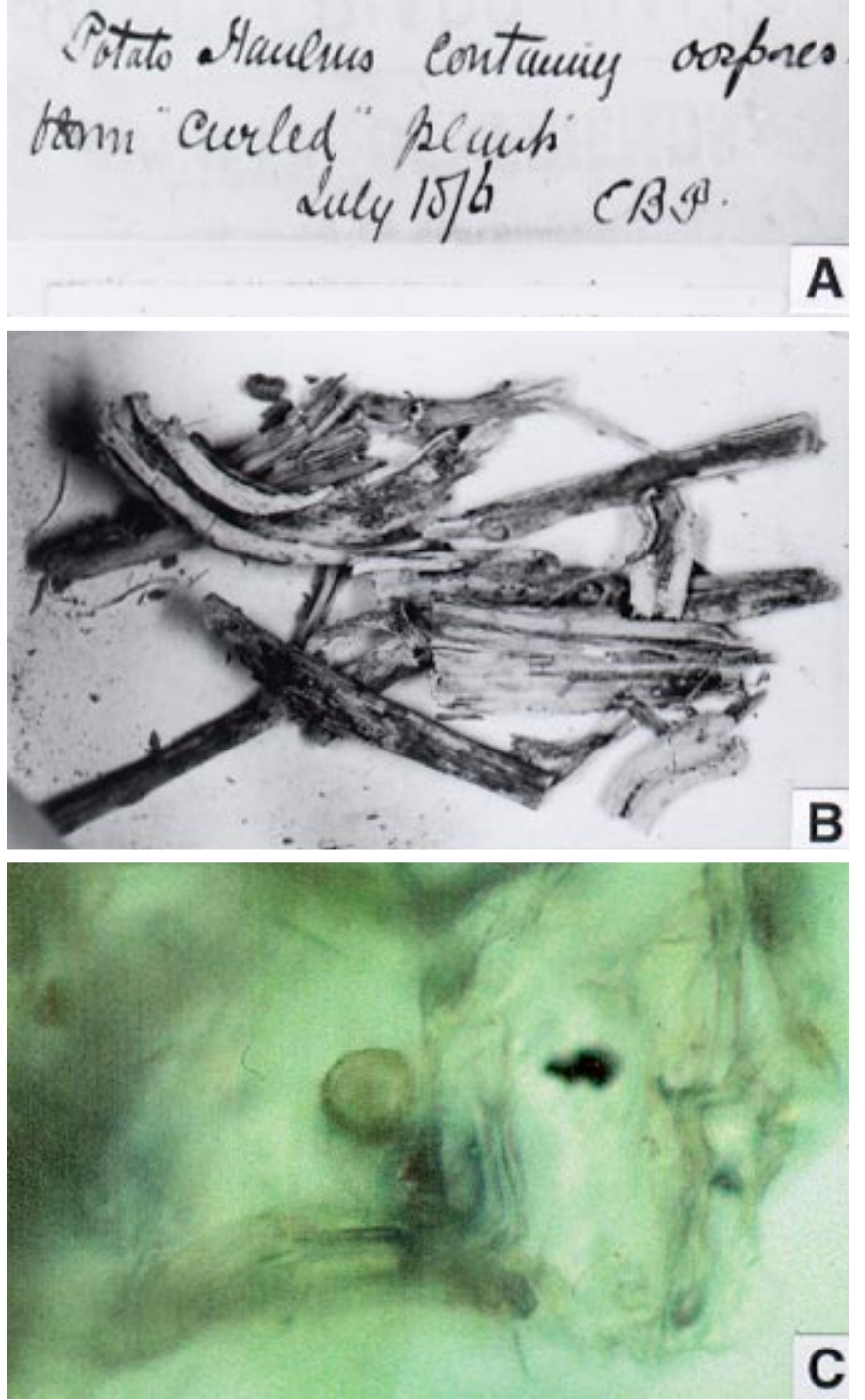

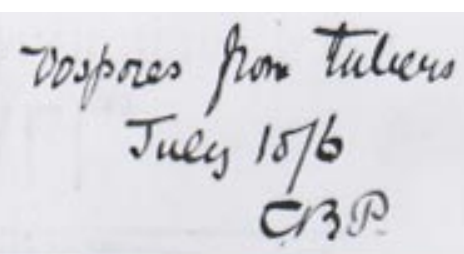

HERBARIUMI.-C.B. Plowright. Peronosfora infectans be by. D
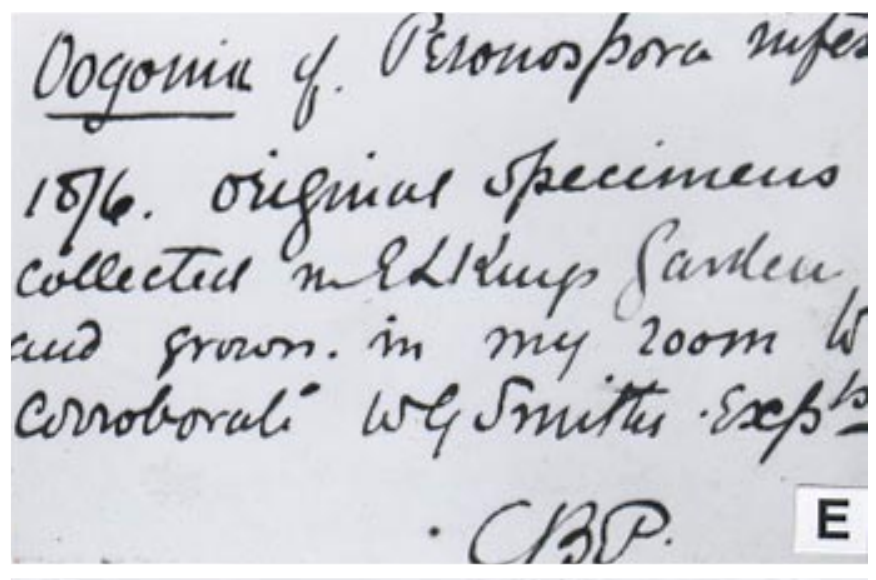

\section{EX HERB. CHARLES B. PIOWRIGHT.}

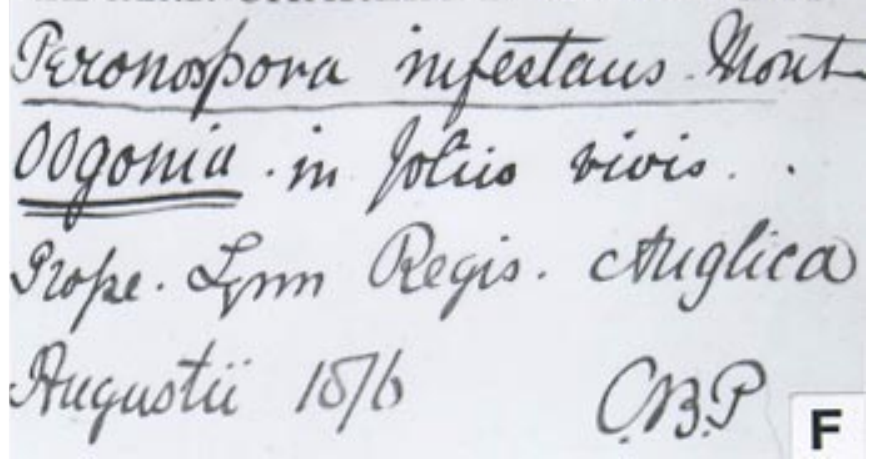

Fig. 5. Charles Plowright's herbarium collection. A, Specimen label indicating the presence of oospores in potato haulms (stems), July 1876 . B, Potato haulms infected with Phytophthora infestans. C, Oospore observed in stem sections made from the specimen. D, Specimen label indicating oospores in tubers, July 1876. E, Specimen label indicating oogonia of Phytophthora infestans, 1876. F, Another specimen indicating oogonia of Phytophthora infestans, 1876. Specimens deposited in the Royal Botanic Gardens Mycology Herbarium, Kew, England. 
ently, all were of the same mating type, since none of the crosses resulted in increased oospore production. The oospores that Clinton observed in culture most likely resulted from self-hybridization of a single mating type of the pathogen. However, the possibility that both mating types were present at this time cannot be ruled out, since Clinton only made five crosses with his isolates (19).

During this same time period, L. R. Jones in Vermont claimed to have found oospores of the potato late blight pathogen (46-48). Clinton examined Jones' papers and wrote on 4 January 1910 in a letter to Farlow at Harvard, "I should have enjoyed going to your lab Saturday with Jones to have heard your and Thaxter's opinion of his 'resting spores' of potato blight. I firmly believe they are not oospores, as they have no oogonium or antheridium and were not smooth, points in which they differ from the other three species of Phytophthora whose oospores I have seen" (20). Jones' publications describe thick, brown, spiny-walled oospores in potato tissue, which were clearly not the oospores of Phytophthora infestans (46-48).

Pethybridge and Murphy corroborated Clinton's observations on the production of oospores of Phytophthora infestans in pure culture, and their work clearly indicated that some of the oospores they observed formed antheridia (56-58). They also stated, "One of us spent a considerable amount of time a few years ago in searching for possible oospores of Phytophthora infestans in the blighted por-

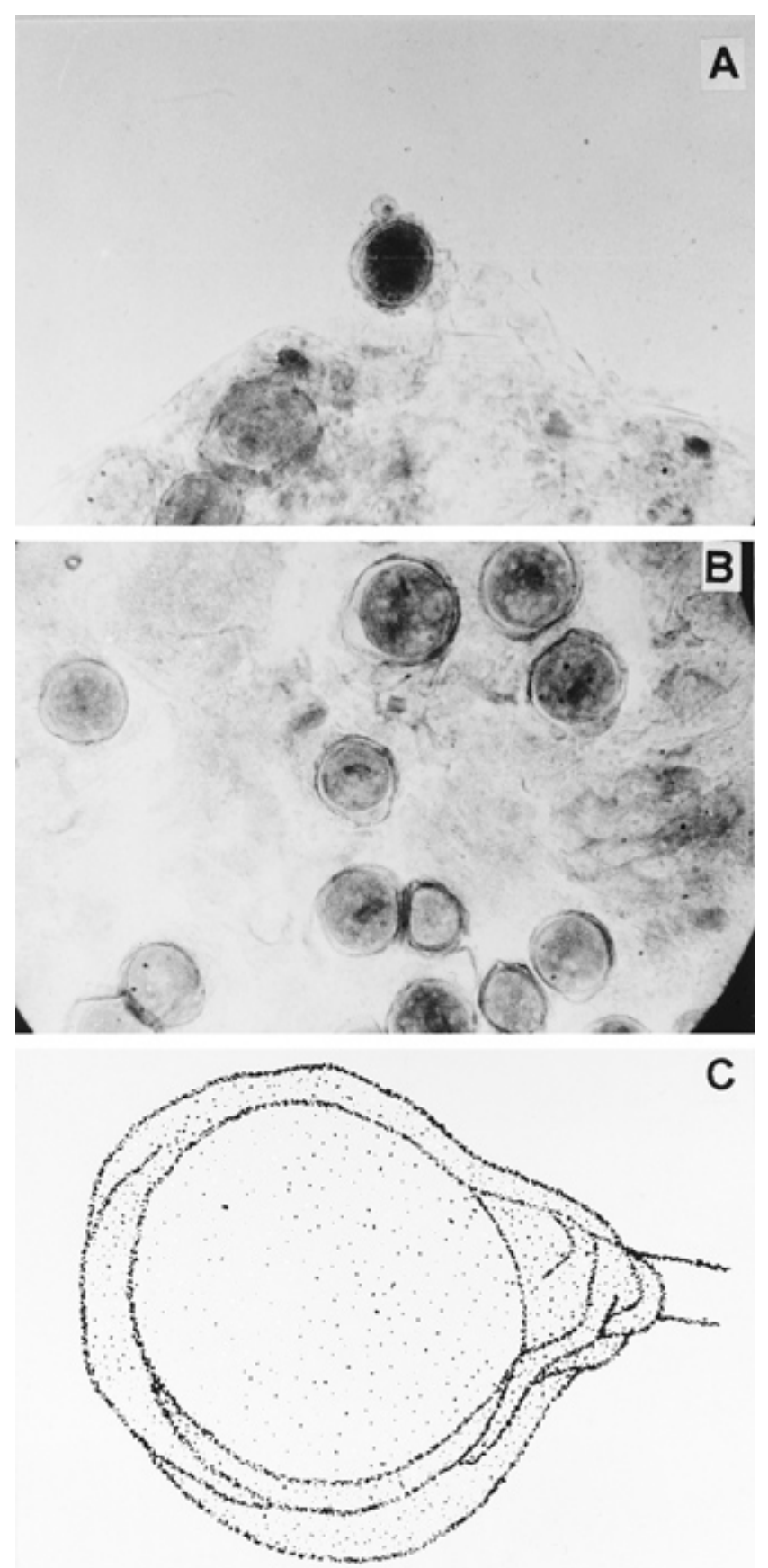

Fig. 7. Oospores of Phytophthora infestans from the master's thesis of M. Kotila Roane, University of Minnesota, January 1946. A, Oogonium with amphigynous antheridia in potato stem epidermis tissue. Aceto-carmine smear. B, Oospores observed in potato stem epidermis from late blight-infected plants, 1946. C, Camera lucida drawing of an oogonium with an amphigynous antheridium from potato tissue collected at Elk River, MN, 1946. 
tions of potato plants. Bodies were found frequently which might have been such structures; but prolonged attempts at causing them to germinate met with absolutely no success; consequently their true nature remains undetermined." Modern researchers familiar with the late blight pathogen recognize that infrequent and low germination of oospores is a constant challenge in research with the pathogen (60).

Clinton himself claimed "to have found bodies in the leaves and tubers of infected plants, but has never been convinced of their real nature" (19). In 1934, Clinton wrote that "the mature stage, like similar fungi, should develop conspicuous, round resting spores within infected tissues but these have never been found in America and apparently it is doubtful if they existed elsewhere. However, that such a stage may exist was proven by the writer in his early cultures of the fungus on artificial media years ago" (23). Despite this statement, Clinton carefully preserved many herbarium specimens from infected plant material from the field that contained putative oospores of Phytophthora infestans (Fig. 6).

In recent studies in my laboratory, we examined four specimens from the National Fungus Collections, USDA, Beltsville, MD. These specimens were collected from potato tubers and dried leaves collected by Clinton in grower fields between 1902 and 1933. These and other specimens contained written evidence of putative oospores on the specimen labels (Fig. 6). Clinton repeatedly observed oospores in decayed tubers and documented and saved his specimens (Fig. $6 \mathrm{~A}$ and $\mathrm{B}$ ). The descriptions written on the specimen labels match those of Phytophthora infestans. We examined four specimens via bright field microscopy for evidence of the pathogen. Oospores resembling those of Phytophthora infestans were observed in three of four samples. Definitive evidence that the oospores found in dried lesions (Fig. 6C) were those of Phytophthora infestans and not some other species of Pythium or Phytophthora is given later in this paper in the section on DNA extraction.

In addition to the extensive research conducted by Clinton, thesis research conducted by M. Kotila (later M. Roane) at the University of Minnesota in 1946 contains some intriguing data concerning the occurrence of oospores of Phytophthora infestans in field samples and inoculated tissue in the United States (52). This work was never published and has been repeatedly overlooked by researchers $(12,24,31,41,42)$. In the course of her work to understand pathogenic variation and develop host resistance to Phytophthora infestans, Kotila observed oospores forming in stem lesions from plants inoculated with field isolates of the pathogen (Fig. 7A and B). She observed the morphology and conditions necessary for formation and germination and studied the ability of the oospores to germinate and infect plants (52). Her observations of abundant oospores in inoculated plant material occurred in 1946, nearly 10 years prior to Gallegly and Galindo's discovery of the A2 mating type in Mexico $(39,78)$. The oospores described by Kotila had amphigynous antheridia (Fig. 7A), and she drew the antheridia with the aid of a camera lucida (Fig. 7C). She observed in potato stem tissue that "as many as 75 to 100 or more oospores were often visible in a single high-powered field" (Fig. 7B). She also observed oospores in naturally infected plant material from the field and observed that within 4 to 6 days after placing tissue in a moist chamber oospores were formed. She demonstrated that oospores were infective by grinding dried lesions, extracting oospores, treating the oospores with ethyl alcohol to destroy mycelium and sporangia, and inoculating plants. Typical late blight lesions occurred in potato tissue inoculated with the oospores (52). In addition, newly formed oospores occurred in the inoculated tissue. Similar treatment of sporangia and mycelium with drying and ethyl alcohol resulted in no infection in control plants, thus suggesting that the oospores were the infective propagule.

Kotila stained the nuclei from potato stems and observed meiosis in the oospores (Figs. 7C and 8). At that time, it was believed that Phytophthora species were haploid. Gametangial meiosis and the diploid nature of oomycetes was not definitively confirmed in Phytophthora species until nearly 20 years later by Sansome $(9,66)$. Kotila, who is now deceased, never published her thesis. Her work is significant in that the oospores she observed were abundant, found in naturally infected plant material, and infective. Her data provide evidence that Phytophthora infestans was not reproducing solely by asexual means in the United States over 50 years ago. Herbarium specimens and slides from her work were not preserved, but her thesis is preserved at the University of Minnesota (52).

\section{CAN DNA BE EXTRACTED FROM OOSPORES OF PHYTOPHTHORA INFESTANS FROM LATE BLIGHT-INFECTED HERBARIUM SPECIMENS?}

Several of the herbarium specimens observed contained microscopic evidence of oospore-like structures (Figs. 5C and 6C). To confirm the identity of oospores in herbarium specimens, DNA was extracted from several samples from G. P. Clinton's collection. The DNA was then PCR-amplified with primers that specifically amplify Phytophthora infestans in potato $(81,82)$. Tissue was first observed for the presence of oospores by mounting in glycerol gelatin or water on sterile glass slides and examining microscopically. Samples from specimens that contained evidence of oospores were removed from slides, placed in microfuge tubes, and stored at $-20^{\circ} \mathrm{C}$. DNA was not diluted prior to PCR, because initial DNA concentrations were low. DNA from each specimen was amplified with both the universal primers ITS 5 and ITS 4 or with a Phytophthora infestans-specific primer, PINF, and ITS 5 (82). DNA was digested with restriction enzyme $R s a \mathrm{I}$, and digested DNA was electrophoresed on a $2 \%$ gel at 25 milliamps for $3 \mathrm{~h}$. Gels were stained in ethidium bromide $(0.5 \mu \mathrm{g} / \mathrm{ml})$ to visualize polymorphisms in amplified DNA fragments.

DNA was successfully amplified from a specimen collected by Clinton in 1902 (specimen number BPI 186893), which was in the
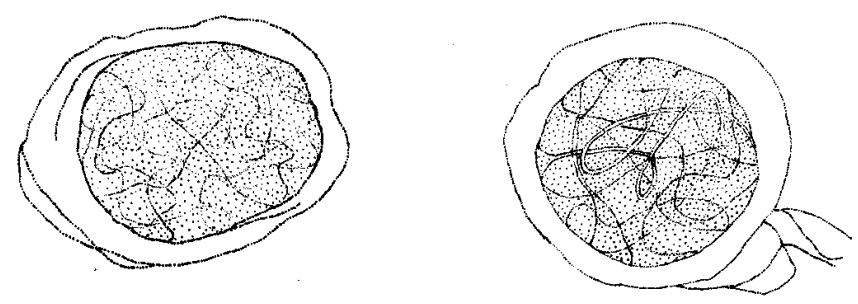

1

$\mathbf{2}$
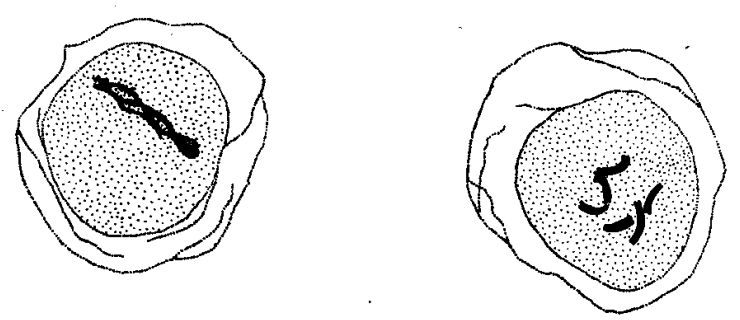

c
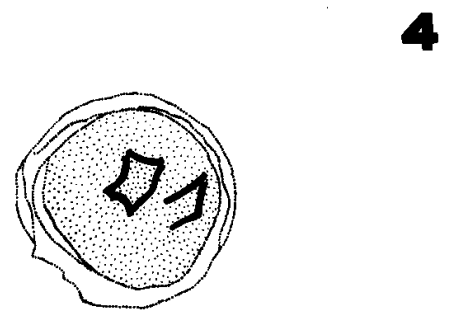

5

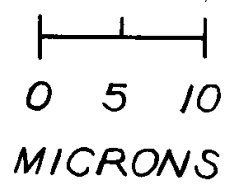

Fig. 8. Nuclei of Phytophthora infestans undergoing meiosis in the oospores from the masters thesis of M. Kotila Roane, 1946. Camera lucida drawings of aceto-carmine smears of unfixed potato stem epidermis. 1, Leptotene; 2, zygotene; 3 , metaphase plate; and 4 and 5, polar views of metaphase. 
U.S. National Fungus Collections (Fig. 6C), using both universal primers ITS 5 and ITS 4 and the Phytophthora infestans-specific PINF primer (Fig. 9, lanes 3 and 8). With primers ITS 5 and ITS 4, a 900-bp product was observed (Fig. 9, lane 3), and this product was identical in size to the product amplified from the Phytophthora infestans-positive control (Fig. 9, lane 2). When DNA was digested with $R s a \mathrm{I}$, restriction fragments approximately 443, 286, 100 , and $80 \mathrm{bp}$ were observed in the DNA from the herbarium specimen (Fig. 9, lane 5), and these fragments were identical in size to those observed from the RsaI-digested mycelium of Phytophthora infestans in the positive control (Fig. 9, lane 4).

DNA was also successfully amplified from the same Clinton specimen (BPI 186893) with the PINF primer and ITS 5 (Fig. 9, lane 8 ). The 600 -bp product was identical in size to the DNA amplified from the mycelium of Phytophthora infestans in the positive control (Fig. 9, lane 7). The PINF primer does not amplify other Phytophthora species that infect potato or other potato pathogens $(65,82)$. Restriction fragment patterns following digestion with $R s a$ I (Fig. 9, lane 10) were also identical to the positive control (Fig. 9, lane 9). The nontemplate controls were consistently negative (Fig. 9, lanes 6 and 11).

Our data indicate that the oospores observed by Clinton in a field sample from specimen BPI 186893 in 1902 were, in fact, oospores of Phytophthora infestans. Clinton remained skeptical in his writing about the occurrence of oospores in plant tissue $(22,23)$. However, it is clear from his notes on specimen labels that he had indeed found oospores in rotted tubers and dried leaves of numerous samples collected from 1902 to 1933 (Fig. 6). Clearly, the pathogen was not reproducing solely by asexual means. It is unclear whether the oospores observed represent a product of sexual reproduction via outcrossing or self-hybridization (8). We have developed PCR markers that can be used to identify certain genotypes of the pathogen and are continuing research on these specimens (C. Trout and J. B. Ristaino, unpublished data).

Our data also demonstrate that it is possible to extract and amplify Phytophthora infestans DNA from dried herbarium tissue (Fig. 6). The PINF primer now provides a powerful tool for accurate identification of Phytophthora infestans DNA in dried materials and will be used in subsequent experiments with additional molecular markers (82). We are expanding our work to amplify DNA from additional herbarium collections of other important 19th and 20th century Phytophthora researchers. Further work is in progress with over 400 herbarium samples collected from late blight epidemics from 1845 to the present. We recently ampli-
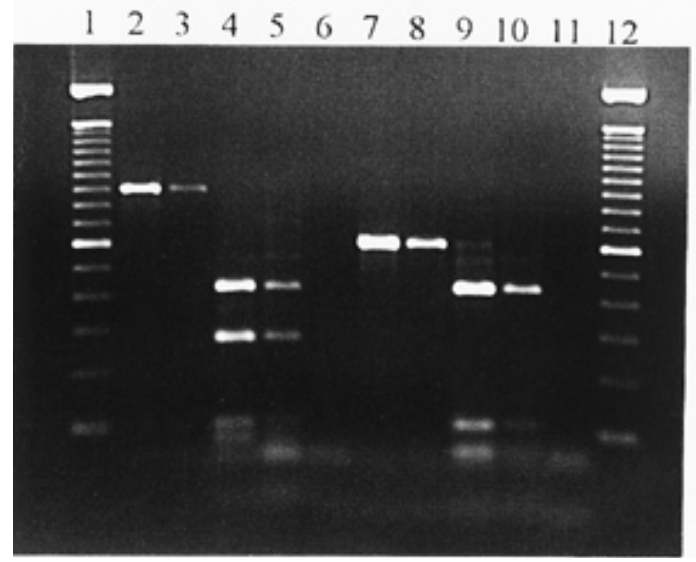

Fig. 9. DNA amplified from G. P. Clinton herbarium specimen BPI 186893. DNA extracted from oospores shown in Figure 6C (specimen BPI 186893) and amplified with ITS 5/ITS 4 primers (lanes 2 to 5) and the PINF/ITS 5 primers (lanes 7 to 10 ). DNA in lanes 2, 3, 7, and 8 was undigested, and DNA in lanes 4, 5, 9, and 10 was digested with RsaI. Lanes 2, 4, 7, and 9 contain DNA from mycelium of Phytophthora infestans in the positive control, and lanes 3, 5, 8, and 10 contain DNA extracted from herbarium specimen BPI 186893. Lanes 6 and 11 contain negative, no template controls. fied Phytophthora infestans DNA from an herbarium sample collected in Poland in 1978 and have succeeded in the amplification and identification of the US-1 genotype of the pathogen from modern fresh and dried lesions and mycelium (J. B. Ristaino, unpublished data). DNA will be deposited back in the respective herbaria collections so that others may use the DNA and validate our research as it progresses.

Herbaria contain important information on the biodiversity of plant pathogens of the past and on the history of our science. Our first results suggest that similar tools could be used to access the wealth of epidemiological information on other pathosystems in the world's herbaria. We are fortunate that mycologists and botanists of the 19th century left these valuable resources for use by plant pathologists of the present. It is important that present day plant pathologists continue to deposit voucher specimens of pathogen-infected plant materials back into existing herbaria.

In 1905, W. G. Farlow in his address before the American Association for the Advancement of Science wrote, "One might perhaps ask: Is the progress of science sometimes like that of the crab, rapid, but not straightforward; or, like the squid, may not the emission of a large amount of printer's ink really conceal a backward movement" (67). Certainly a tremendous amount of "printer's ink" has been used publishing on the late blight pathosystem, yet the disease continues to devastate potato and tomato production worldwide. Microscopic and molecular studies of historical collections, although not straightforward, will continue to provide new information about this and other plant disease epidemics of the past.

\section{ACKNOWLEDGMENTS}

This research was supported, in part, by funds from the North Carolina State University (NCSU) International Programs Office and special grant 97-34362-4946 from the USDA, CSREES. I thank A. Rossman, research leader of the Systematic Botany and Mycology Laboratory and director of the U.S. National Fungus Collections, USDA, Beltsville, MD; D. Pfister, Asa Gray professor at the Farlow Herbarium, Harvard University; and D. Pegler, head of mycology, and M. Chase, head of molecular systematics of the Royal Botanic Garden, Kew, England, for providing access to specimens and laboratory space during my sabbatical leave and for providing encouragement for the research. I thank archivists L. Price of the Royal Botanic Gardens and L. DeCesare of the Farlow Reference Library for archival letters. I also thank C. Trout, postdoctoral associate, and $\mathrm{M}$. Madritch, undergraduate research assistant, for DNA work with herbarium specimens in my laboratory. P. Petersen and L. Campbell at NCSU, and S. Anagnostakis, Connecticut Agricultural Experiment Station, provided bibliographic information on G. Clinton. C. Roane, Virginia Polytechnic Institute, and N. Anderson, University of Minnesota, provided bibliographic information on Martha Kotila Roane's thesis research. I thank J. Thomas for providing access to the Phytotron facility at NCSU for the DNA work.

\section{LITERATURE CITED}

1. Abad, Z. G., and Abad, J. A. 1997. Another look at the origins of late blight of potatoes, tomatoes, and pear melon in the Andes of South America. Plant Dis. 81:682-688.

2. Andrivon, D. 1996. The origin of Phytophthora infestans populations present in Europe in the 1840's: A critical review of historical and scientific evidence. Plant Pathol. 45:1027-1035.

3. Berkeley, M. J. 1846. Observations, botanical and physiological on the potato murain. J. Hortic. Soc. Lond. 1:9-34.

4. Berkeley, M. J. 1875. Letter to W. G. Farlow on June 26, 1875. Farlow Herbarium and Reference Library, Harvard University, Cambridge, MA.

5. Berkeley, M. J. 1875. Letter to W. G. Farlow on July 10, 1875. Farlow Herbarium and Reference Library, Harvard University, Cambridge, MA.

6. Berkeley, M. J. 1876. Letter to Joseph Hooker. Directors Correspondence 79:348. Mycology Herbarium, Royal Botanic Garden, Kew, England.

7. Berkeley, M. J. 1876. Letter to a British colleague (probably John Firminger Duthie). Mycology Herbarium, Royal Botanic Garden, Kew, England. 
8. Bourke, A. 1993. 'The Visitation of God'? The Potato and the Great Irish Famine. Lilliput Press, Dublin.

9. Brasier, C. M., and Sansome, E. 1975. Diploidy and gametangial meiosis in Phytophthora cinnamomi, P. infestans, and P. drechsleri. Trans. Br. Mycol. Soc. 65:49-65.

10. Bruns, T. D., Fogel, R., and Taylor, J. 1990. Amplification and sequencing of DNA from fungal herbarium specimens. Mycologia 82:175-184.

11. Chase, M. R., Etter, R. J., Rex, M. A., and Quattro, J. M. 1998. Extraction and amplification of mitochondrial DNA from formalin-fixed deepsea mollusks. Biotechniques 24:243-247.

12. Chycoski, C. I., and Punja, Z. K. 1996. Characteristics of populations of Phytophthora infestans from potato in British Columbia and other regions of Canada during 1993-1995. Plant Dis. 80:579-589.

13. Clinton, G. P. 1905. Letter to W. G. Farlow on November 25, 1905. Farlow Herbarium and Reference Library, Harvard University, Cambridge, MA.

14. Clinton, G. P. 1906. Letter to W. G. Farlow on April 10, 1906. Farlow Herbarium and Reference Library, Harvard University, Cambridge, MA.

15. Clinton, G. P. 1906. Letter to R. Thaxter on December 15, 1906. Farlow Herbarium and Reference Library, Harvard University, Cambridge, MA

16. Clinton, G. P. 1908. Letter to R. Thaxter, November 13, 1908. Farlow Herbarium and Reference Library, Harvard University, Cambridge, MA.

17. Clinton, G. P. 1908. The artificial cultures of Phytophthora, with special reference to oospores. Conn. Agric. Exp. Stn. Rep. 1907-1908: 891-903.

18. Clinton, G. P. 1909. Artificial cultures of Phytophthora with special reference to oospores. Science 29:271-272.

19. Clinton, G. P. 1910. Oospores of potato blight, Phytophthora infestans. Conn. Agric. Exp. Stn. Rep. 1909-1910:753-774.

20. Clinton, G. P. 1910. Letter to W. G. Farlow on January 4, 1910. Farlow Herbarium and Reference Library, Harvard University, Cambridge, MA.

21. Clinton, G. P. 1910. Letter to W. G. Farlow on February 4, 1910. Farlow Herbarium and Reference Library, Harvard University, Cambridge, MA.

22. Clinton, G. P. 1911. Oospores of Phytophthora blight. Science 33:744-747.

23. Clinton, G. P. 1934. Plant pest handbook for Connecticut II. Diseases and injuries. Conn. Agric. Exp. Stn. Bull. 358:314

24. Deahl, K. L., Groth, R. W., Young, R., Sinden, S. L., and Gallegly, M. E. 1991. Occurrence of the A2 mating type of Phytophthora infestans in potato fields in the United States and Canada. Am. Potato J. 68:717-726

25. DeBary, A. 1861. Die gegenwartig herrschende Kartoffelkrankheit, ihre Ursache und ihre Verhutung. Arthur Felix, Leipzig, Germany.

26. DeBary, A. 1863. Researches sur le developpment de quelques Champignons parasites. Memoire pour servir de supplement aux Travaux sur la question des Generations dites spontanees. Ann. Sci. Nat. (4e Ser. Bot.) 20:5-148.

27. DeBary, A. 1874. Letter to W. G. Farlow on December 10, 1874. Farlow Herbarium and Reference Library, Harvard University, Cambridge, MA.

28. DeBary, A. 1875. Letter to W. G. Farlow on December 25, 1875. Farlow Herbarium and Reference Library, Harvard University, Cambridge, MA

29. DeBary, A. 1876. Researches into the nature of the potato-fungusPhytophthora infestans. J. R. Agric. Soc. 12:239-268.

30. Doyle, J. J., and Dickson, E. E. 1987. Preservation of plant samples for DNA restriction endonuclease analysis. Taxon 36:715-722.

31. Drenth, A., Tas, I., and Gover, F. 1994. DNA fingerprinting uncovers a new sexually reproducing population of $P$. infestans in the Netherlands. Eur. J. Plant Pathol. 100:97-107.

32. Farlow, W. G. 1875. Letter to M. J. Berkeley on November 18, 1875. Mycology Herbarium, Royal Botanic Gardens, Kew, England.

33. Farlow, W. G. 1875. The potato rot. Bull. Bussey Inst. 1:319-338.

34. Farlow, W. G. 1876. Synopsis of the Peronosporaceae of the United States. Bull. Bussey Inst. 1:426-427.

35. Fraile, A., Escriu, F., Aranda, M. A., Malpica, J. M., Gibbs, A. J., and Garcia-Arenal, F. 1997. A century of tobamovirus evolution in an Australian population of Nicotiana glauca. J. Virol. 71:8316-8320.

36. Francis, D. M., and St. Clair, D. A. 1993. Outcrossing in the homothallic oomycete, Pythium ultimum, detected with molecular markers. Curr. Genet. 24:100-106.

37. Fry, W. E., and Goodwin, S. B. 1997. Resurgence of the Irish potato famine fungus. Bioscience 47:363-371.

38. Fry, W. E., Goodwin, S. B., Dyer, A. T., Matuszak, J. M., Drenth, A., Tooley, P. W., Sujkowski, L. S., Koh, Y. J., Cohen, B. B., Spielman, L. J., Deahl, K. L., Inglis, D. A., and Sandlan, K. P. 1993. Historical and re- cent migrations of Phytophthora infestans: Chronology, pathways, and implications. Plant Dis. 77:653-661.

39. Gallegly, M. E., and Galindo, J. 1958. Mating types and oospores of Phytophthora infestans in nature in Mexico. Phytopathology 48:274-277

40. Goodwin, S., Cohen, B., and Fry, W. 1994. Panglobal distribution of a single clonal lineage of the Irish potato famine fungus. Proc. Natl. Acad. Sci. 91:11591-11595.

41. Goodwin, S. B., and Drenth, A. 1997. Origin of the A2 mating type of Phytophthora infestans outside Mexico. Phytopathology 87:992-999.

42. Goodwin, S. B., Sujkowski, L. S., Dyer, A. T., Fry, B. A., and Fry, W. E. 1995. Direct detection of gene flow and probable sexual reproduction of Phytophthora infestans in northern North America. Phytopathology 85: 473-479.

43. Herrmann, B., and Hummel, S. 1994. Ancient DNA. Recovery and Analysis of Genetic Information from Paleontological, Archaeological, Museum, Medical, and Forensic Specimens. Springer-Verlag, New York.

44. Hibbett, D. A., Grimaldi, D., and Donoghue, M. J. 1997. Fossil mushrooms from miocene and cretaceous ambers and the evolution of the homobasidiomycetes. Am. J. Bot. 84:981-991.

45. Hohl, H., and Iselin, K. 1984. Strains of Phytophthora infestans from Switzerland with A2 mating type behavior. Trans. Br. Mycol. Soc. 83:529-530.

46. Jones, L. R. 1909. Resting spores of the potato fungus. Science 30:813-814.

47. Jones. L. R. 1910. Further studies of Phytophthora infestans. Science 31: 752-753.

48. Jones, L. R., Giddings, N. J., and Lutman, B. F. 1912. Investigations of the potato fungus Phytophthora infestans. Pages 1-100 in: Univ. Vt. State Agric. Exp. Stn. Bull. 168.

49. Judelson, H. S. 1996. Recent advances in the genetics of oomycete plant pathogens. Mol. Plant-Microbe Interact. 9:443-449.

50. Judelson, H. S. 1997. Expression and inheritance of sexual preference and selfing in Phytophthora infestans. Fungal Gen. Biol. 21:188-197.

51. Judelson, H. S., Spielman, L. J., and Shattock, R. C. 1995. Genetic mapping and non-mendelian segregation of mating type loci in the oomycete, Phytophthora infestans. Genetics 141:503-512.

52. Kotila, M. A. 1946. Studies on the potato late blight fungus, Phytophthora infestans. M.S. thesis. University of Minnesota, St. Paul.

53. Large, E. C. 1962. The Advance of the Fungi. Dover Publications, Inc., New York

54. McCormick, F. A. 1938. George Perkins Clinton (1867-1937). Phytopathology 28:379-387.

55. Niederhauser, J. S. 1991. Phytophthora infestans: The Mexican connection. Pages 25-45 in: Phytophthora. J. A. Lucas, R. C. Shattock, D. S. Shaw, and L. R. Cooke, eds. Cambridge University Press, Cambridge, England.

56. Pethybridge, G. H. 1913. Investigations on potato disease: Pure cultures and resting spores. Dep. Agric. Tech. Instr. Ireland 13:10.

57. Pethybridge, G. H. 1921. Some recent work on the potato blight. Pages 112-126 in: Rep. Int. Potato Conf. Royal Horticultural Society, London.

58. Pethybridge, G. H., and Murphy, P. A. 1913. On pure cultures of Phytophthora infestans De Bary and the development of oospores. Sci. Proc. R. Dublin Soc. 13:566-588

59. Pfister, D. 1985. A bibliographic account of exsiccatae containing fungi. Mycotaxon 23:1-140.

60. Pittis, J. E., and Shattock, R. C. 1996. Viability, germination and infection potential of oospores of Phytophthora infestans. Plant Pathol. 43: 387-396

61. Plowright, C. W. 1876. On a certain phase of the potato disease. Gardener's Chron. 4:214.

62. Plowright, C. W. 1876. Some further observations upon the potato disease. Gardener's Chron. 6:241.

63. Reddick, D. 1939. Whence came Phytophthora infestans? Chron. Bot. 5: 410-412.

64. Ristaino, J. B., Abad, Z. G., and Ugent, D. 1995. Tracking ancient epidemics: Survey of plant pathogens of preceramic Peru. Pages 226231 in: Proc. Phytophthora Conference, 150. Boole Press, Ltd., Dublin, Ireland.

65. Ristaino, J. B., Madritch, M., Trout, C. L., and Parra, G. 1998. PCR amplification of ribosomal DNA for species identification in the plant pathogen genus Phytophthora. Appl. Environ. Microbiol. 68:948-954

66. Sansome, E. 1961. Meiosis in the oogonium and antheridium of Pythium debaryanum Hesse. Nature 191:827-828.

67. Setchell, W. A. 1927. William Gilson Farlow. Mem. Natl. Acad. Sci. 21: $1-22$

68. Shattock, R. C., Tooley, P. W., and Fry, W. E. 1986. Genetics of Phytophthora infestans: Characterization of single-oospore cultures from A1 isolates induced to self by intraspecific stimulation. Phytopathology 76:407-410. 
69. Shaw, D., Fyfe, A., Hibberd, P., and Abdel-Sattar, M. 1985. Occurrence of the rare A2 mating type of Phytophthora infestans on imported Egyptian potatoes and the production of sexual progeny with A1 mating types from the UK. Plant Pathol. 34:552-556.

70. Smith, W. G. 1875. The resting spores of the potato disease. Gardener's Chron. 4:35-36.

71. Smith, W. G. 1875. The resting spores of the potato disease. Gardener's Chron. 4:68-70,101.

72. Smith, W. G. 1875. The resting spores of the potato fungus. Mon. Microscopical J. 24:110-129.

73. Smith, W. G. 1875. The resting spores of the potato fungus. Nature 12:234.

74. Smith, W. G. 1875. The resting spores of the potato fungus. Quart. J. Micro. Sci. 15:360-363.

75. Smith, W. G. 1876. The resting spores of the potato fungus. Gardener's Chron. 6:10-12.

76. Smith, W. G. 1876. The potato fungus. Germination of the resting spores. Gardener's Chron. 6:39-42.

77. Smith, W. G. 1876. The potato fungus. Germination of the resting spores. Mon. Microscopical J. 16:120-135.

78. Smoot, J. J., Gough, F. J., Lamey, H. A., Eichenmuller, J. J., and Gallegly, M. E. 1958. Production and germination of oospores of Phytophthora infestans. Phytopathology 48:165-171.

79. Taylor, J. W., and Swann, E. 1994. Dried samples: Soft tissues. DNA from herbarium specimens. Pages 166-181 in: Ancient DNA. B. Herrmann and S. Hummel, eds. Springer-Verlag, New York.

80. Tooley, P. W., Therrien, C. D., and Ritch, D. L. 1989. Mating type, race composition, nuclear DNA content, and isozyme analysis of Peruvian isolates of Phytophthora infestans. Phytopathology 79:478481.

81. Trout, C. L., and Ristaino, J. B. 1997. Fungicides affect mating behavior in Phytophthora infestans. Phytopathology 87:S98.

82. Trout, C. L., Ristaino, J. B., Madritch, M., and Wangsomboondee, T. 1997. Rapid detection of Phytophthora infestans in late blight-infected potato and tomato using PCR. Plant Dis. 81:1042-1048.

83. Zan, K. 1962. Activity of Phytophthora infestans in soil in relation to tuber infection. Trans. Br. Mycol. Soc. 45:205-221. 